International Journal of Scholarly Papers for Media and Communications

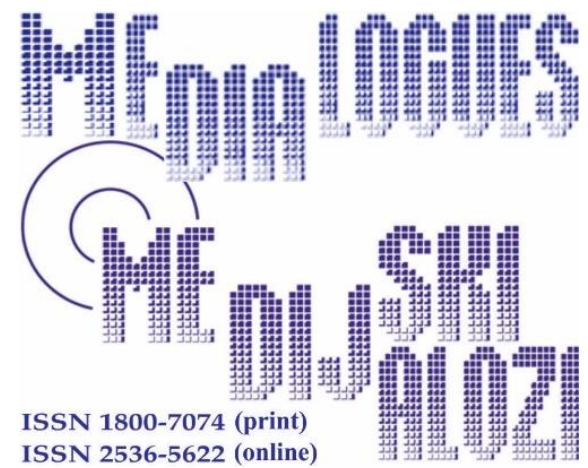

Basic Hrvatin, S. (2013), „The Press Crisis”,Media Dialogues / Medijski dijalozi, Vol. 14, No. 2, pp. 7-24.

\title{
The Press Crisis
}

\section{Associate Professor SANDRA BASIC HRVATIN,}

Faculty of Humanities Koper, University of Primorska

European commission expert,

Koper, Slovenia

\begin{tabular}{|c|c|l|}
\hline $\boldsymbol{A} \boldsymbol{R} \boldsymbol{T} \boldsymbol{I} \boldsymbol{C L} \boldsymbol{E}$ & Received: November 15, 2021 & Revised from: December 14, 2021 \\
$\boldsymbol{I} \boldsymbol{N} \boldsymbol{F} \boldsymbol{O}$ & Accepted: January 15, 2021 / & Available online: April 15, 2021 \\
\hline $\boldsymbol{D O I}$ & doi.org/10.14254/1800-7074/14-2/1 \\
\hline
\end{tabular}

\begin{abstract}
The newspaper industry is in crisis and with it journalism in ge-neral. The crisis started years ago and has recently reached the critical point. The consequences are dire, and the worst is that the collapse of the newspaper industry presents a serious threat to the very foundations of democracy. To make the bad situation worse, there is still no consensus among experts on how to proceed to rescue the collapsing sector. However, one thing is clear: the business model on which the newspaper industry rested for decades is no longer sustainable. One of the reasons is that that the dependence on advertising revenue brought most newspapers to their knees, serving
\end{abstract}


the interests of profit-driven media owners and advertisers rather than the public interest. The author looks into various proposals for future funding models, assessing their advantages and shortcomings. She argues for elaborate and innovative mechanisms of state support to the media that will take into account the changes brought about by the Internet and will place more power in the hands of readers. Finally, she lists proposals that could be used as a starting point in the effort to revitalize the newspaper sector.

KEYWORDS: Newspaper industry, crisis, public interest, online media, communications.

\section{INTRODUCTION - THE KILLING AND THE SUICIDE OF THE NEWSPAPER INDUSTRY}

Amid concerns over media concentration during the 1960s, the renowned American journalist A. J. Liebling wrote that the disappearance of each newspaper meant the disappearance of a point of view or at least of a place where it could have found expression. A city with just one newspaper or a city with a morning and an evening newspaper published by the same outlet is like a man with one eye only - and a glass one at that. Half a century or so later, the number of such cities is vast. Moreover, there are entire regions and states where media ownership is concentrated in the hands of few individuals, while daily newspapers with long-standing tradition have been gradually disappearing. Popular views about journalists and journalism have essentially changed over this 50-year period as well. The bold men (note that the image was never that of a woman) with a notepad and pen painstakingly researching stories about political or corporate corruption in an effort to uncover the truth for the benefit of readers (Humphrey Bogart in Deadline - U.S.A., Jimmy Stewart in The Philadelphia Story, or the unforgettable Robert Redford and Dustin Hoffman in All the President's Man) were replaced by millions of individuals who post items on the Internet contributing their own bits of truth. The city with one eye has been replaced with the city with a million eyes, says Mark Bowden (2009) ${ }^{1}$.

In 2009, the American non-governmental organization Pew Research for the People and the Press ${ }^{2}$ published the findings of the regular annual opinion survey about Americans' views on the news media. The interviews (conducted in July of that same year with 1,506 adult Americans) showed that $63 \%$ of respondents thought that news stories were often untrue - the percentage almost twice as large as that in 1985, when the survey was first conducted. Approximately the same number of res-

\footnotetext{
1 Mark Bowden, Atlantic, The Story Behind the Story, October 2009, http://www.theatlantic. com/doc/200910/media

${ }^{2}$ Pew Research Center, "Public Views of News Media 1985-2009, Accuracy Rating Hits Two-Decade Low", http://people-press.org/report/543/\#prc-jump
} 
pondents (60\% compared to $45 \%$ in 1985) thought that media coverage was biased. The Republicans' traditional criticism of the liberal media's servility to Democrats was countered by Democrats who increasingly believed (67\% of respondents) that the media favored a specific side over the other. The ideological divide of the media space is, according to this survey, most evident from the answers relating to The New York Times - the newspaper boasting the status of opinion leader and of the most credible information source as chosen by American journalists caused the most severe split between the Republicans and the Democrats.

Similarly, the authors of the report on the state of American news media published yearly by the Project for Excellence in Journalism ${ }^{3}$ argue that the current crisis will have a long-term effect on the media. The recession that struck the media industry is compounded by the "recession of trust" on the part of readers, listeners and viewers. When assessing the work of the news media, $32 \%$ of respondents described it as immoral (compared to $13 \%$ in 1985), $22 \%$ said that it was unprofessional and $55 \%$ that it was politically biased. More than one third of respondents (32\%) thought that the way in which the media operate is detrimental to democracy.

The analysts of the Project for Excellence in Journalism drew attention to the changing trends within the media industry as early as $2008^{4}$. They pointed out that one of the key trends was the turning of news into a service (no matter where the news was published). News was no longer a consumer product, but an unfinished story that could be checked for credibility several times (with various sources), compared (across various sources) and changed (through one's own action). Rather than facts, consumers of news want assistance, advice, guidance and moral teachings, or instructions on how to proceed and obtain as much further information as possible about the issues in which they are interested. News organizations (the media) are no longer the ultimate destination for news consumers. The era of "fenced (media) gardens" has come to an end. Media companies (formerly accustomed to "monopoly and political nepotism") must today compete on the market where supply and demand are governed by the quality of the services offered. The attention of service users, on the other hand, is not guided by standards set by the media industry (selection on the basis of professional demands in journalism), but by personal preferences. The media industry has increasingly been turning into an industry that endeavors to appeal to the tastes of its consumers. The key role here is played by advertising.

\section{QUO VADIS THE MEDIA INDUSTRY?}

\footnotetext{
${ }^{3}$ Project for Excellence in Journalism, 2009, The State of the News Media 2009, An Annual Report on American Journalism, http://www.stateofthemedia.org/2009/index.htm

${ }^{4}$ Project for Excellence in Journalism, 2008, The State of the News Media 2008, An Annual Report on American Journalism, http://www.stateofthenewsmedia.com/2008/
} 
The media industry is in crisis. It is not solely the crisis of the business model that affects only media owners and profits, but a crisis of journalism about which its protagonists refuse to talk, cannot talk, are not allowed to talk, or do not want to talk. In their public appeals to rescue the collapsing industry, publishers of daily newspapers (in Slovenia and elsewhere) start from the correct premise that the shaping of media policy is closely related to the issue of public interest. The question, however, is not only who determines the public interest but primarily what the public interest within the media field actually is. Too often the public interest is simplistically equated with the national (or European) interest and described in terms of economic categories put forward as the basis for obtaining state subsidies (the financial support by the state is supposed to be provided only to the media or programming content that serve the public interest), or with a specific sector of the media (so, for example, thanks to their news-provision role, the newspapers are classified as serving the public interest).

If in shaping media policy the public interest is defined as described above, then the practical consequences are what we have in Slovenia right now: the state (politics) acts subjectively and voluntarily, subsidizing only specific media in accordance with its own preferences or expected political influence. However, the public interest is not something that can be defined in the legislation or by media owners who exploit their property in the same way as any other owner - to make profit. The public interest is a subject of citizens' public debate and ongoing negotiations. The media as such are not an a priori public interest, nor do they a priori serve the public interest. They are a form of organization used by the public to accomplish communi- cation. Therefore, the public interest is communication, public debate, the possibility of publicly expressing one's opinion and influencing political decisions. A law can-not define the public interest, but it can set down clear criteria (and safety valves) which the state should observe when allocating budget funds (state aid) to the communication projects (not only media projects) that enable citizens to actively participate in the public sphere.

In its public appeals, the newspaper industry explains its importance for citizens (the public interest) by saying that the newspapers are the "tip of the information pyramid." The argument goes that for centuries the print media (primarily daily newspapers) have been the most influential setters of the news agendas, which earned them the reputation of credible sources in matters relating to public issues. The news coverage provided by the newspaper industry is supposedly the foundation of the news coverage across the entire media industry - radio, television and online media. Put differently, newspapers are believed to produce news, while other media mainly recycle news items and repackage the stories. While it may be true that the newspapers represent the largest source of content for the online media, it is not true that they are the most important information providers.

Another argument often used in explaining the special (and important) role of the newspaper industry is that precisely the newspapers create content that is not 
motivated by commercial interests (profit). Its proponents frequently refer to foreign correspondent networks, culture and other newspaper sections whose production is very costly. Undoubtedly, viewed from the perspective of economic indicators, investigative journalism and the coverage of issues that do not come under the tabloid category require a lot of professional effort, knowledge and investment in human resources (journalists) on the part of media owners. While this type of content indeed does not contribute to the basic goal of the owner (profit), it is an invaluable source of information for the public about the issues which they cannot judge based on their own experience or about which they have insufficient knowledge. Data, however, show that precisely this content is subject to the most severe "streamlining", or put differently, its share in the entire newspaper output has been declining.

The findings of the Media Standards Trust survey Shrinking World revealed a drastic decline in the coverage of international issues in the British press ${ }^{5}$. The survey that looked into the international news coverage by four quality British newspapers during the period 1979-2009 showed that the number of articles covering international issues declined by $39 \%$ over the 30 -year period under scrutiny. The report claims that a matter of concern is not solely the smaller number of international news items, but the changed perception of what international news actually is. Of the two stories rela- ted to India and covered by the Mirror in the first quarter of 2010, one was about the arrest of two UK nationals who were accused of spying at the airport, and the other about the spiritual enlightenment of the American star Lindsay Lohan during her visit to India. On the other hand, India itself as one of the most expanding economies, its military power and internal political issues were never the subject of the coverage (Willmot, 2010).

The "shrinking of the world" in newspapers automatically means the shrinking of the world in the heads of readers. The readers see the world beyond their home country borders only through the glasses of the national interest (coverage of the developments in other countries is related to a specific state's political and economic interests), or in terms of accidents and excesses of celebrities. Probably the most tragic consequence of the shrinking news agenda is the dependence of citizens on the very limited number of media sources that exchanged their information provision role for that of the commentator. Owing to the competition presented by television as the primary source of information, the newspapers have increasingly been turning from news providers into commentators, abandoning news and rather presenting and selling views of, as A. Currah $(2009$, p. 65) says, "star commentators" and "super journalists". If the corporate newspaper industry no longer has monopoly over the production and distribution of news, the question that imposes itself is who has taken over its role? If the media no longer do it, who will watch the watchdogs?

\footnotetext{
${ }^{5}$ Media Standards Trust, 1.11.2010. Shrinking world: The decline of international reporting in British press", http://mediastandardstrust.org/publications/shrinking-world-the-decline-of-internationalreporting-in-the-british-press/
} 
The renowned American media researcher and newspaper analyst Paul Starr (2009) ${ }^{6}$ writes that the era of the domination of newspapers has been drawing to a close, and that we are in for an era of corruption. The news coverage, says Starr, is not the only function that the media performed over the centuries since their inception. Their basic function was to provide citizens with an effective means of control over the state and its institutions. This function is today jeopardized. The media business, which is deeply interspersed with the interests of capital, is in crisis. Its rescue is a matter of preserving the foundations of the democratic system. If the watchdogs that should identify corruption are corrupt themselves, who then still has the power (and responsibility) to operate in the interest of the public, asks Starr?

Responding to Starr's criticism of the media industry, Yochai Benkler (2009), the author of The Wealth of Networks ${ }^{7}$, says that the media performed its watch-dog function far from ideally. During the Bush administration, large American media took part in the manipulation of the public opinion and many among them continue to do so. The model of information production and distribution that has been in place in the mass mediated world should, in Benkler's opinion, be replaced with the new model of networked communication. The corporate media industry no longer holds monopoly over the production and distribution of information. It is now dispersed and networked in the form of a vast number of individual or personal views and information sources available on the web.

The current economic crisis has revealed that the large profits earned by the media were not derived from the products or services production (media content) and their sale to the best customers. The real profit emerged from the process of complex financial transactions, complex financial products and their (re)selling to potential customers. The American newspapers began to confront this issue during the early 21 st century. For years, the average annual profit of the newspaper industry amounted to 26 percent (Schiffrin, 2010 p. 14). Florence Noiville, a literary editor for Le Monde says in her book J'ai fait HEC et je m'en excuse (I Went to Business Schools and I Apologize - Stock, 2009) that most of the renowned French business schools do not teach students how to manage a business or how the economy operates, but how to maximize profit, including through "painless" layoffs. Precisely this rescue "model" - newsroom layoffs and the shrinking of news agenda - was chosen by large newspaper owners. Let us have a look at certain data.

In 2008, the newspaper industry in the US laid off 16,000 employees, with the further 10,000 losing their jobs in the first half of 2009 (Pérez-Peña, 2009). For the first time since 1978, the number of journalists working for the news media fell under

\footnotetext{
${ }^{6}$ For a historical overview of the development of news media in the USA and a critical view on their social role see Paul Starr, 2004. The Creation of the Media. Political Origins of Modern Communications. New York: Basic Books.

${ }^{7}$ See also Benkler, Yochai. 2006. The Wealth of Networks. How Social Production Transforms Markets and Freedom. London: Yale University Press, http://yupnet.org/benkler
} 
40,000 (The Pew Research Center's Project for Excellence in Journalism, The State of the News Media, 2013). During the same period, certain renowned newspapers drastically curtailed the international news coverage as well as the coverage of local politics although data showed that local politics is most vulnerable to corruption (Downie and Schudson, 2009). Readers are not blind to the effects of the decadeslong cost-cutting within newsrooms. Almost one third of American readers stopped reading newspapers because they no longer provide information they grew accustomed to finding there (The State of the News Media, 2013).

In the early 2009, the American newspaper industry saw its sales drop by 2.6 billion dollars, which translates into a 10.6 percent drop in the copies sold. Put differently, this means that every day 44 million copies less were sold, which is the largest drop in the newspaper sales since 1940. It was influenced by the 16.8 percent drop in advertising revenues in 2008, and a further 28 percent drop at the end of September 2009 (Pérez-Peña, 2010). According to the Newspaper Association of America, advertising revenue continued to fall in 2012. For every 16 dollars lost in print newspaper advertising there is only one dollar earned from online advertising. In 2011, this ratio was 10 to 1 , meaning that the revenue from online advertisements is much lower than expected (The State of the News Media, 2013).

These trends are not characteristic of the American market only. Data for France are similar. Le Figaro, for decades the most widely read and the most successful daily newspaper in France, saw the decline of EUR 40 million in advertising revenue between 2003 and 2007 (from 120 million to 90 million). Le Monde's financial loss is even greater. Between 2001 and 2008, its advertising revenue was halved. In 1970, its share in the total income was 60 percent, while today it is barely 20 percent. Similarly, the total number of French newspaper copies was halved during the two decades (1970-2007), falling from 3.8 to 1.9 million copies only. In Great Britain, the most affected were tabloids (Schiffrin, Ibid., p. 62).

\section{THE CRISIS OF WHAT?}

Ever since 2009, the media industry of the western world has been drawing attention to the crisis within the media sector ${ }^{8}$. What is interesting, though, is how it presented the crisis to the public and to whom it turned for help. Unlike Le Monde Diplomatique, which appealed for help to its readers to protect the content that they could not find in other media, the majority of other newspapers turned to their governments. The Slovenian newspapers were no exception - after a decade of financi-

\footnotetext{
${ }^{8}$ The 2012 report on the state of the American news media points out that the vanishing of newspapers is a threat to democracy. Most people obtain information about the work of state institutions from newspapers. If the newspapers cease to exist, the question that remains unanswered is who will perform this role in the future. See The State of the News Media 2012, http://stateofthemedia.org/2012/ newspapers- building-digital-revenues-proves-painfully -slow/Richard Pérez-Peña, "US Newspaper Circulation Falls 10\%," New York Times, October 27, 2009, B3
} 
ally lucrative operation accompanied by the layoffs of journalists and the shrinking of coverage of key social issues, when confronted with the crisis for which they themsel- ves were responsible, they turned to the government with the request for a specific state aid, i.e. zero VAT.

The crisis of the newspaper industry is a consequence of wrong decisions on the part of media owners (not only Slovenian) and their unwillingness to understand changes and respond to them. For decades, the only development "strategy" at the basis of the media industry was prevention of competition and the raising of the entry threshold for new publishers (Knee et al., 2009). At the same time, precisely the newspaper industry was the first to begin the true persecution of the web media, web journalism and bloggers, accusing them of being responsible for the shrinking newspaper readership that supposedly exchanged newspaper reading for the superficial browsing of the web in pursuit of free of charge content, for the flourishing of "copy-paste" journa- lism, plagiarism and worthless journalism in general. While this may be true, the questions that usually remain without answers are: why do multitudes of readers turn away from newspapers and opt for the leisurely browsing of the web? Why are people willing to sacrifice their spare time to create and recycle web content for free? Why does not the newspaper industry contend with large telecoms and news aggregators for its just share of profit from content provision? Why should only consumers pay the price for irresponsible media policy?

The print media may be in crisis, but the reader's interest in content is not affected by it. Walter Isaacson of The Time has established that the number of newspaper readers has been increasing (including that of young readers) and that newspaper content is ever more popular (Isaacson, 2009). The problem is that increasingly fewer people are willing to pay to read this content. The traditional tripartite funding system under- lying the newspaper industry - subscription, newsstand sales, advertising - increasingly depends on one source only - advertising. The irony of the "free lunch" busi- ness model is that the advertisers are no longer willing to pay the "full" price for content production (journalistic work). The only beneficiaries of this "free lunch" model are internet providers who charge users for their access to the Internet where they can then search content "for free." In Isaacson's opinion, a solution for the print media industry would be the introduction of so-called micropayments, i.e. the payment of specific content which would force journalists to produce content that consumers are willing to pay. If journalism becomes dependent on readers and their payments, says Isaacson, it would return to where it should have always stayed - to the public.

Discussions on the potential financing models for the news industry mainly rest on wrong prescriptions for the disease it has been diagnosed with. Micro- payments ${ }^{9}$

\footnotetext{
${ }^{9}$ Newspapers offering online content have been increasingly introducing one or another type of digital subscription. One of the more efficient models is a metered model used by The New York Times. Digital subscription is a matter of survival for newspapers. Since 2007, 15 daily newspapers on average
} 
for online content or non-profit media organizations cannot provide an efficient remedy for the current crisis. A micropayment model has already been tur- ned down by the Internet users, while a non-profit ownership model would be encumbered by insufficient endowments, so it cannot become the dominant model for the entire newspaper sector (Robinson, 2010).

Since the newspapers have not come up with an adequate funding model for the future, it can be expected that they will attempt to obtain the missing funds (missing with regard to expected profit) from the government and Internet users. The first step will be to establish connections with mobile operators who will offer to their subscribers a "bundling" option - a tablet at a reduced price plus a newspaper subscription. This means that the price a consumer will pay to a mobile operator for a "tool" will include content (newspaper). Imagine yourself going to a shop to buy a specific product and realizing that the price of that product is twice the price you would pay if you bought it along with two additional items which you do not need. If this happened in a grocery store, everyone would protest. However, if the lower price is tied to buying a newspaper or a mobile phone, we are willing to buy something that we do not need or do not want only to obtain a lower price (which is at any rate never too low, since at the end of the day we overpay everything). The new-spapers that so far based their sales strategies on the "tie-in sales" (e.g. a new-spaper plus a book, with a book being a complement to a newspaper), will themselves beco-me a complement, a "gift," when you buy another item (a tablet). It would be too naïve to expect that in such a constellation journalism will pursue the public interest.

\section{HOW CAN JOURNALISM BE RESCUED?}

The basic question with which future media policies will need to deal is how to rescue journalism, and European policy (particularly the European Commission policy) is a clear indicator of the destiny that awaits the media. In the parlance of Brussels politicians, the term "media" has been substituted with the collocation "content creators," and the term "media industry" with "cultural and creative industry" other hand, in response to the increasingly frequent appeals to save the media industry, the European Parliament produced a vague document proposing the shaping of a European public sphere that should be created by (pan)European media. Instead of concentrating on the information and communication needs of European citizens,

\footnotetext{
disappea- red from the American market every year, which amounts to app. 1 percent of the entire newspaper indus- try. Many experts predict that within the next five years the majority of the daily newspapers will print only Sunday editions, while all other editions will go online. See The Pew Research Center's Project for Excellence in Journalism, The State of the News Media 2012, An Annual Report on American Journalism.

10 "Commission launches public consultation on future of cultural and creative industries" IP/10/466, Brussels, 27.4.2010 (http://europa.eu/rapid/pressReleasesAction.do?reference=IP/10/466\&format= HTML\&aged $=0$ \&language $=$ EN \& guiLanguage $=$ en
} 
European parliamentarians devoted attention primarily to their own needs: how to ensure a greater media coverage of the work of EP and European institutions ${ }^{11}$.

If the media and journalism no longer exist and if they have been replaced with creative content producers, then it is clear that no one (including newspapers) any longer has a privileged role in serving the public interest. The British National Union of Journalists drew attention to the "death of journalism" saying that it is "not merely the loss of jobs, it is the death of democracy ${ }^{12}$." In appealing to the EU to take urgent steps and rescue the newspaper industry, they proposed certain measures that could help resolve the crisis. Among other things, they proposed that the governments should introduce a strict implementation of copyright rules to prevent the theft of content produced by journalists, prohibit low-paid "internship" journalistic work and the reprinting of journalistic articles via email or discussion boards, scrap the funding for the media that slashed their editorial staff, continually monitor the situation of press freedom in all member states, prevent ownership concentration, prohibit crossmedia ownership, and support public broadcasters in developing online services. Finally, their main proposal is the introduction of what has been termed a "European democracy voucher," effectively meaning that citizens would finance journalism directly. According to this scheme, citizens would annually receive special certificates that could be used to pay access to the media (regardless of the platform) that ensure the sufficient scope of "hard news". The scope and content of this news would be prescribed by national legislations, while citizens would be free to choose which media they want to co-fund. Instead of a governmental body deciding which media outlet to support, the support will be provided by citizens (through certificates) so the "survival" of individual media will be entirely in their hands.

From what is said above it is clear that the media industry has come to the "critical juncture" as Robert McChesney (2005, p. 9) put it, with old institutions collapsing and transforming even before the new ones came into shape. How is it possible to democratize the existing corporate and profit-oriented media to serve the public interest? The existing model on which the production and distribution of news is based is in need of radical transformation. As early as 2009, Robert McChesney and John Nichols (2009) argued in The Nation that it was time for the state to come up with an adequate subsidy policy (regulation) to rescue American journalism. The urgent measures they proposed included the following:

- The subsidizing of distribution, i.e. the elimination of postage for all periodicals that earn less than 20 percent of their revenue from advertising, with this mea-

\footnotetext{
${ }^{11}$ On journalism and new media - creating a public sphere in Europe. 2.7.2010. (2010/2015 (INI)). http://www.europarl.europa.eu/sides/getDoc.do?type=REPORT\&reference=A7-2010$0223 \&$ language $=$ EN\#title2

${ }^{12}$ Death of Journalism - more than just loss of jobs. http://www.nujcec.org/ brussels/index.php/latestnews/curr_evts/death-of-journalism-more-than-just-loss-of-jobs
} 
sure meant to be applied to journals of opinion that offer quality content and to investigative journalism projects.

- Tax reliefs for readers - the state should grant a tax relief for the first 200 dollars spent for the daily newspapers that provide a specific amount of news content (e.g. 24 broad pages every day), are published five times a week at least and have less than 50 percent advertising. The government would then make a payment to the newspaper, depending on the choice of individual citizens.

- Support for schools and universities for establishing print, radio, television and internet media - to be a journalist and to know how to create media should become basic civil right and duty.

- An adequate funding of the public and community media - the resources should be used primarily for the production of content on the local level.

Many things have happened in the meanwhile, since the publication of this article. The media industry crisis grew so severe that in the US it triggered a serious public debate on not only how to rescue the disappearing media companies but primarily on what the future role of the media and journalism should be. The Democratic Senator Benjamin Cardin tabled a bill in March 2009 called the Newspaper Revitalization $\mathrm{Act}^{13}$. It was meant to help the vanishing local and regional newspaper survive by transforming them into not-for-profit organizations.

In the book The Death and Life of American Journalism, McChesney and Nichols (2010) have proposed new proactive interventions into the media sphere. The authors argue that throughout their long history, the American media and American journalism received extensive state subsidies which, unfortunately, did not bring about the greater influence of the public but a greater profit for owners. McChesney and Nichols also stress that the existing corporate media should be transformed into non-profit and not-for-profit (low profit) institutions. The corporate media sector, whose business model is based on advertising revenue, is in crisis as is the model of superficial, trivial, recycling, PR-driven and scandal-pursuing journalism. Apart from organizational changes, McChesney and Nichols (Ibid., p. 159) also propose that the collapsing corporate media should transform into the "post-corporate" digital newspapers, that the public and community media should transform into true civic and democratic media, and that with the help of state subsidies innovative forms of web journalism should be supported. If the state was willing to invest billions of dollars to rescue the financial and economic sectors (e.g. the car industry), one would expect that it would set aside the same sum to rescue the industry whose "products" enable democracy to function.

With the development of the Internet and new online media, citizens who for decades had no option of taking part in public communication, obtained a chance to intervene into journalists' monopoly over the production and dissemination of infor-

\footnotetext{
${ }^{13}$ http://www.reuters.com/article/idUSTRE52N67F20090324.
} 
mation. The issue that should be the subject of the public debate is not whether journalism is possible without journalists, or whether various forms of content published on the web deserve to be called the media, but whether we as citizens will have access to all the necessary information needed for our active participation in public life. The future of the media and journalism is no longer the question that concerns media owners (and their rights) but the fundamental question of the future of democracy.

Columbia Journalism Review (a publication of the faculty of journalism of the Columbia University in New York), commissioned Leonard Downie and Michael Schudson (2009) to carry out research on the reconstruction of American journalism. Their article appeared in October 2009 opening a broad public debate on the future of journalism. In contrast to McChesney and Nichols, who advocate a comprehensive state aid to the media and journalism, Downie and Schudon concentrated on various forms of indirect state support to the most jeopardized segments of the media industry - the news sector and investigative journalism. To boost various sources of independent news coverage, Downie and Schudson proposed the following measures:

- The tax department or the Congress should support the establishment or reshaping of independent news organizations that predominantly cover public issues into non-profit organizations or low-profit corporations that work in the public interest.

- Individual supporters, donators and foundations should provide greater support for the media organizations which in the past devoted attention to the key public issues and responsible coverage.

- Public radio and television stations should reorganize their operation in such a way that the greatest part of their airtime is devoted to news relating to the local communities in which they operate. This would inevitably entail the reshaping of the Corporation for Public Broadcasting, a larger financial support from the state and changes in guidelines on their operation.

- Both public and private universities should, by virtue of their education role, be- come a sustainable source of accountable, local and national journalistic work. U- niversities should have their own media, recruit top journalists to perform the teaching tasks, and become live laboratories for digital innovations and all forms of innovative collection, dissemination and sharing of information.

- It would be necessary to establish a national Fund to support the local coverage that would be partly financed from resources accrued by the Federal Communication Commission and partly from additional funds obtained from the users of telecommunication services, television and radio frequencies and internet service providers. The resources thus obtained would be distributed by way of the public calls for applications, and would be awarded by the Fund's local councils.

- Journalists, non-profit organizations and state institutions should invest more effort to increase the practical usefulness of information and access to it, sustain 
various platforms for information collection and distribution selected by citizens themselves, and raise public awareness of the existing sources that could become an important impetus for citizen's mobilization.

The Knight Foundation, renowned for its funding of non-profit media projects, led an extensive national debate with the participation of many public figures, journalists and NGOs' representatives, followed by a book containing recommendations on the protection of the information needs of (primarily local) communities in the digital $\mathrm{era}^{14}$. The commission has established that the current financial crisis faced by many private media presents a serious threat to democracy. If citizens cannot obtain relevant and credible information, they cannot participate in the co-administration of the state, either on the local or on the national level. Well-informed communities can improve their "information health" by supporting innovative business models for the media that will ensure quality journalism, by increasing the support for the public broadcasters endeavoring to satisfy the information needs of local communities, and by supporting education institutions and non-profit organizations in developing new forms of journalistic activities based on information sharing in various local environments. In addition to emphasizing active support for local media organizations, the report devotes special attention to the activities oriented towards strengthening information and communication knowledge of citizens and to the issue of equal access to the latest technologies for every individual. The result of such active policy is expected to be the development of new participative forms of political activity in which various IC platforms will be a vital tool in the shaping of common public space.

The lively public debate on the future of journalism in the US resulted in various proposals on how to democratize the media and how to place them back at the core of the democratic public sphere. What is interesting is that most of these proposals refer to the positive effects of various types of state support in Europe (primarily the efficient model of financing the public media). In contrast to the US, where the breakdown of the existing media models provoked serious deliberations as well as misgivings about the role of the state in meeting the citizens' information needs, Europe (under pressure of these same American media corporations) has been shifting away from the public media model and state support for the media sector. Paradoxically, the EU, which over the decades of its existence failed to shape common media policy, became the biggest advocate of the corporative media model even as it was breaking down in the US.

\footnotetext{
14 The Knight Commission on the Information Needs of Communities in a Democracy, Informing Commu- nities: Sustaining Democracy in the Digital Age (Knight Foundation, 2010) http://www. knightcomm.org/wpcotent/uploads/2010/02/Informing_Communities_Sustaining_Democracy_i n_the_Digital_Age.pdf
} 


\section{WHAT SHOULD BE DONE?}

Instead of inventorying the more or less catastrophic situation of the media industry, let us rather take a look at what could be done to weather the crisis. In late January 2009, The New York Times published a commentary by David Swensen and Michael Schmidt (2009) on the future of American newspapers. In line with the well known statement of the great American President Thomas Jefferson, that wellinformed citizens are the foundation of democracy, the rescue of American media was in their opinion mandatory. Swensen and Schmidt proposed that newspapers should be transformed into non-profit organization which would free them from the obligati- on to serve the media owner (and profit) and enable them to turn to their primary task - serving the interests of citizens. To preserve and even revitalize the newspapers, say the authors, it would be necessary to transform newspaper companies into non-profit institutions funded through donations, like universities and colleges. Donations would ensure greater autonomy and would protect newspapers from the economic forces that now keep them on their knees. The hitherto costcutting approach to the crisis will in most cases have long-term effects on content. The decades of cutbacks (the so-called 3P model - people, paper, price) resulted in the radically smaller number of journalists and other employees (between 2002 and 2006, the American media reduced the foreign bureaus staff by one quarter); certain newspapers reduced the number of pages, others dropped certain sections and supplements, or changed format etc. A trend currently on the rise is the "free lunch" model (free of charge pa- pers), with the entire price of the newspaper being covered by advertisers.

Donations would transform newspapers into strong, more stable and more independent organizations that would be able to serve the public good more efficien- tly, explain David Swensen and Michael Schmidt. Journalists would not be exposed to the pressure exerted by media owners or advertisers. Similar to the scholarship model in education institutions, newspapers would derive revenue from subscription fees for printed copies and access to their web content. Donations would be adjusted to newspapers' revenues. However, since only several foundations and wealthy individuals have enough money for donations, enlightened philanthropists must take steps now, say Swensen and Schmidt.

Dan Kennedy 82009) responded to their proposals in The Guardian, a newspaper itself owned by a non-profit foundation. According to Kennedy, to be able to establish non-profit media, the American legislation should first be changed, since it "robbed" non-profit institutions of their First Amendment rights. Swensen's and Schmidt's idea has a positive and a negative side. The worst outcome, says Kennedy, is that "under US law, our self-styled watchdogs of democracy would become lapdogs, eschewing partisan politics in order to obtain a precious federal tax exemption." As a matter of fact, under the current American legislation, non-profit organizations cannot "influence legislation" or "participate in any campaign activity for or against political candidates." What is then left to the media that are prevented 
from covering political issues and the operation of governmental bodies? Moreover, this prohibition has further implications. As a matter of fact, the prohibition to "influence legislation" means that even those non-profit organizations that would campaign for changes in legislation relating to abortion and same-sex marriages, or against politicians who endeavor to restrict the rights of these groups, would be prevented from engaging in the struggle. As Kennedy says, the right to free speech (even if applied to the operation of non-profit organizations exempt from tax payment), is the right of everyone and not only of those with whose opinions we agree.

For decades, the media industry gained profit from deregulation, which in successive waves diluted demands to serve the public interests, say John Nichols and Robert McChesney (2009). It is time for the state to rescue American journalism through an adequate subsidy policy (regulation).

Le Monde diplomatique acted in response to the crisis of journalism and the media several times. As early as 2005, its former editor Ignacio Ramonet (2005) publicly appealed to the readers to actively engage in the struggle for the right to obtain verified and credible information. This is also the context in which it is possible to place the appeal of the German philosopher Jürgen Habermas (2007) published in Süddeutsche Zeitung in May 2007 (indeed, not well received in Germany) for a state support to quality newspapers. Without newspapers of opinion we cannot hope to have a public space for citizens' debate, and no democracy can afford to have such communication deficit. Habermas (2008) repeated his appeal in 2008 in an interview for Die Zeit in which he emphasized that certain delicate areas of our lives must not be exposed to the risks generated by stock market speculations. Democracy includes certain public goods, for example, undistorted political communication, which cannot be tailored to the needs of profit-making investors. The citizens' need for information cannot be satisfied in a culture of fast-digested political sound bytes that flourish in the media landscape dominated by commercial television.

\section{CONCLUSION: ONE STEP FORWARD, TWO STEPS BACKWARD - OR THE OTHER WAY ROUND}

The creators of new media policy should elaborate in detail the new mechanisms of state support to the media. Rather than media owners, it is media content producer and citizens who need support. A state subsidy should be given only to the socially responsible media that respect their employees' rights and professional standards, operate in a transparent manner and serve the public interest.

Non-profit ownership cannot become the dominant model within the newspaper sector, because endowments would not be sufficient to sustain it. Below we list several alternative funding methods: 
- A part of the monthly fee paid to Internet access providers could be used to finan- ce the online news media based on the percentage of people who consume their content.

- Internet retail shops. These shops would connect producers and consumers and substitute the sale of advertising space; they would be used for transactions between companies and customers, while one part of the transaction cost would be paid to the web page that serves as the entry point.

- Boutique news. It would be produced by topmost journalistic and research teams specializing in individual areas and offered to customers who seek an in-depth coverage of a specific subject (see, for example, the project ProPublica - Journalism in the Public Interest, Kaiser Health News in Inside Science) ${ }^{15}$;

- News aggregators such as Google could devote part of their income to news organizations that produce information.

- Journalistic collectives. With the power shifting away from media institutions and towards individual journalists, the latter could establish collectives through which they could offer their content. Collectives would not be composed of professional journalists only but also authors who have professional knowledge about a specific topic. The collectivist journalism model would be a joint project of all members of the collective and the funding would be based on the number of published texts. Media collectives would be legal persons catering for the needs of their members. Their members would be both "suppliers" (authors) and "customers" (readers). A media collective would be self-managed by its members who would also choose the management model. Each member of a collective would take commitment to respect the professional standards in journalism. A collective would be funded exclusively through the voluntary monthly contributions of its members. The amount of such a contribution would be determined by members themselves, and the report on the spending of funds would be published monthly. Access to content would be granted only to members, but the collective would also have the option of selling its members' texts to other media companies for a pre-determined price. Media collectives would therefore be self-managed community media. The line ministries would secure initial capital from the budget ne- eded to establish a media collective. The amount would correspond to the share of content and number of members (e.g. for each member, the collective would receive a 10 euro extra subsidy a year).

- Relevant institutions should ensure free access to analogue frequencies for NGOs and local communities for the production of non-commercial radio and television programs. These programs would also be funded from members' contributions and the local community budget. The local community would cover the employment costs for journalists and other media workers.

The above-said is just a proposal for the future discussion about the new ways of organizing the public media sphere. The crisis of media industry is not the crisis

\footnotetext{
${ }^{15}$ www.propublica.org, www.kaiserhealthnews.org. in www.insidescience.org
} 
of the underlying business model, but of mass communication in general. The industry that has for years been serving the interests of owners and payers (advertisers) can no longer be sensitive to the needs of citizens. For decades now, citizens have been mere statistical exchange currency in national surveys on readership, or percentages in audience ratings. The time has come to take our communication rights in our own hands. This time, let the price of the "free lunch" be paid by those who "cooked" it.

\section{REFERENCES}

Benkler, Y. (2009), "Correspondence: A New Era of Corruption?", The New Republic, 4.3. 2009. (http://www.tnr.com/politics/story.html?id=c84d2eda-0e 95- 42fe-99a2-5400e7dd8eab).

Bowden, M. (2009), „The Story Behind the Story“, Atlantic, October, http://www. theatlantic. com/doc/200910/media

Currah, A. (2009), Navigating the Crisis in Local and Regional News: A Critical Review of Solutions, http://reutersinstitute.politics.ox.ac.uk/fileadmin/ documents/Publicati-ons/Navigating_the_Crisis_in_Local__ Regional_ News_Final.

Downie, L.Jr. Schudson, M. (2009),“The Reconstruction of American Jornalism,” Columbia Journalism Review, October 19.

Habermas, J. (2007), "Keine Demokratie Kann sich das leisten”, Süddeutsche Zeitung, 16.5.2007, http://www.sueddeutsche.de/,ra412/kultur/artikel/455/ $114341 /$,

Habermas, J. (2008), “Nach dem Bankrott”, Die Zeit, 6.11 .2008 (http://www.zeit.de/ 2008/46/ Habermas?page=all,)

Isaacson, W. (2009), "How to Save Your Newspaper+", The Time, 5.2.2009 http:// www.time.com/time/business/article/0,8599,1877191,00.html

Kennedy, D. (2009), "Lifting the tax on free speech", The Guardian, 3.2.2009, http:// www.guardian.co.uk/commentisfree/cifamerica/2009/feb/03/newspapers-nonprofit-endowments

Knee, J.A., Greenwald, B.C., Seave. A. (2009), The Curse of The Mogul. What's wrong with the world's leading media companies, Portfolio Hardcover.

McChesney, R.W. (2005), Communication Revolution. Critical Junctures and the Future of Media, The New Press, New York.

McChesney, R., John Nichols, J. (2009), "The Death and Life of Great American News-paper", The Nation, March, 18. http://www.thenation.com/doc/ 20090406/ nichols_mochesney).

McChesney, R., Nichols. J. (2010), The Death and Life of American Journalism. The Media Revolution That Will Begin the World Again, Nation Books, Philadelphia, PA. 
Nichols, J., McChesney, R.W. (2009), “The Death and Life of Great American Newspapers", The Nation, 18.3.2009, http://www.thenation.com/doc/ 20090406/ nichols_mochesney)

Pérez-Peña, R. (2009), "US Newspaper Circulation Falls 10\%”, New York Times, October 27.

Pérez-Peña, R. (2010), “Times Company Reports Profit for Quarter and Year”, New York Times, February 10, p. $\mathrm{B}_{5}$

Ramonet, I. (2005), „Final edition for the press”, Le Monde Diplomatique, January 2005, http://_mondediplo.com/2005/01/16press

Robinson, J. (2010), "Times and Sunday Times paywall content has 362.000 monthly users", The Guardian, 26.10.2010.

Schiffrin, A. (2010), Words \& Money, Verso, London, New York

Starr, P. (2009), "Goodbye to the Age of Newspaper (Hello to a New Era of Corruption)", The New Republic. 4.3.2009. http://www.tnr.com/politics/story.html? $\mathrm{id}=\mathrm{a} 4 \mathrm{e} 2 \mathrm{aafc}-\mathrm{cc} 92-4 \mathrm{e} 79-90 \mathrm{~d} 1-\mathrm{db} 3946 \mathrm{a} 6 \mathrm{~d} 119 \& \mathrm{p}=1$.

Swensen, D., Schmidt, M. (2009), „News You Can End Endow“, The New York Times, 27.1.2009 (http://www.nytimes.com/2009/01/28/opinion/28swensen. html?_r=1\& page wanted=all,.

The Pew Research Center's Project for Excellence in Journalism, The State of the News Media (2013), An Annual Report on Americann Journalism, http:// stateofthemedia. org/2013/newspapers- stabilizing-but-still-threatened/

Willmot, O. (2010), "The decline of foreign correspondent", New Statesman, 1.11, http:// Www.newstatesman.com/international-politics/2010/11/foreigninternational-british. 